BMJ Open

Diabetes

Research

\& Care

\title{
Establishing the national top 10 priority research questions to improve diabetes- related foot health and disease: a Delphi study of Australian stakeholders
}

\author{
Byron M Perrin (1) , , ${ }^{1,2}$ Anita Raspovic, ${ }^{3}$ Cylie M Williams, ${ }^{4}$ Stephen M Twigg, ${ }^{2,5,6}$ \\ Jonathan Golledge (D) , 2,7,8 Emma J Hamilton, ${ }^{9,10}$ Anna Crawford, ${ }^{11}$ \\ Carol Hargreaves, ${ }^{12}$ Jaap J van Netten (D) , ${ }^{13}$ Nytasha Purcell, ${ }^{2}$ \\ Peter A Lazzarini (iD) 2,14,15
}

To cite: Perrin BM, Raspovic A, Williams CM, et al. Establishing the national top 10 priority research questions to improve diabetes-related foot health and disease: a Delphi study of Australian stakeholders. BMJ Open Diab Res Care 2021;9:e002570. doi:10.1136/ bmjdrc-2021-002570

- Additional supplemental material is published online only. To view, please visit the journal online (http://dx.doi. org/10.1136/bmjdrc-2021002570).

Received 27 August 2021 Accepted 15 October 2021

Check for updates

\section{(c) Author(s) (or their} employer(s)) 2021. Re-use permitted under CC BY-NC. No commercial re-use. See rights and permissions. Published by BMJ.

For numbered affiliations see end of article.

Correspondence to Dr Byron M Perrin; b.perrin@latrobe.edu.au

\section{ABSTRACT}

Introduction Diabetes-related foot disease is a large cause of the global disease burden yet receives very little research funding to address this large burden. To help address this gap, it is recommended to first identify the consensus priority research questions of relevant stakeholders, yet this has not been performed for diabetes-related foot disease. The aim of this study was to determine the national top 10 priority research questions for diabetes-related foot health and disease from relevant Australian stakeholders.

Research design and methods A modified three-round Delphi online survey design was used to seek opinions from relevant Australian stakeholders including those with diabetes or diabetes-related foot disease or their carers (consumers), health professionals, researchers and industry. Participants were recruited via multiple public invitations and invited to propose three research questions of most importance to them (Round 1), prioritize their 10 most important questions from all proposed questions (Round 2), and then rank questions in order of importance (Round 3).

Results After Round 1, a total of 226 unique questions were proposed by 210 participants (including 121 health professionals and 72 consumers). Of those participants, 95 completed Round 2 and 69 completed Round 3. The top 10 priority research questions covered a range of topics, including health economics, peripheral neuropathy, education, infection, technology, exercise, and nutrition. Consumers prioritized peripheral neuropathy and prevention-related questions. Health professionals prioritized management-related questions including Australia's First Peoples foot health, health economics and infection questions.

Conclusions These priority research questions should guide future national research agendas, funding and projects to improve diabetes-related foot disease burdens in Australia and globally. Future research should focus on consumer priority research questions to improve the burden of diabetes-related foot disease on patients and nations. Further research should also investigate reasons for different priorities between consumers and health professionals.

\section{INTRODUCTION}

Diabetes-related foot disease (DFD) causes $\sim 2 \%$ of the global disability burden

\section{Significance of this study}

What is already known about this subject?

- National priority research questions are needed to drive high-impact healthcare research, but, to our knowledge these have not been identified for diabetes-related foot disease anywhere.

What are the new findings?

- National priority research questions for diabetesrelated foot disease stakeholders are identified for the first time.

- Consumers (patients and carers) prioritized peripheral neuropathy and prevention-related questions.

- Health professionals prioritized health economic and management-related questions.

- Australia's First Peoples health was the top priority question for health professionals.

How might these results change the focus of research or clinical practice?

- These national priority research questions should guide future national research agendas, funding and projects, and help ensure that patient priorities are the focus of future research to improve the burden of diabetes-related foot disease in Australia and globally.

and $\sim 1 \%-2 \%$ of all healthcare costs, ${ }^{1-5}$ yet receives the equivalent of $<0.01 \%$ of all healthcare research funding awarded. ${ }^{6} 7$ Furthermore, DFD causes $\sim 60 \%$ of the global diabetes disability burden and $\sim 33 \%$ of all diabetes healthcare costs, ${ }^{1-5}$ yet receives $<0.2 \%$ of all diabetes research funding awarded. ${ }^{6} 7$ This large gap between the comparatively high disease burden caused by DFD and the comparatively low research funding it receives to address this burden, ${ }^{5-7}$ has seen DFD labeled the world's 'least known major health problem'? 
The development of a national research agenda is one method recommended to begin to close the gap for health conditions where research funding is not commensurate with the disease burden they create..$^{7-10}$ However, to develop such a national research agenda, it is critical to first identify the national priority research questions that relevant stakeholders consider most important to address to improve the condition's burden..$^{9-11}$ Such national priority research questions are also becoming more widely used by research granting bodies to ensure that research funding is targeted towards the most important research priorities. ${ }^{9} 12$

While global DFD bodies have published priority areas for future research according to the gaps or uncertainties in the existing international literature,${ }^{13-18}$ no studies to our knowledge have investigated the priority research questions that relevant stakeholders consider important for diabetes-related foot health and disease, such as patients/carers (consumers), health professionals, researchers and industry stakeholders. Thus, the aim of this study was to determine the national top 10 priority research questions to improve diabetes-related foot health and disease according to relevant stakeholders in Australia.

\section{RESEARCH DESIGN AND METHODS \\ Design}

The study was designed as a three-round modified Delphi online survey ${ }^{19}$ aligning with that used to determine the top 10 national research priorities in type 2 diabetes in the UK. ${ }^{90}$ The working group leading this research included Australian researchers, health professionals and consumers in the field of DFD ('the authors') appointed by the national peak body for DFD in Australia, Diabetes Feet Australia (DFA).

\section{Participants}

Eligible participants were residents of Australia who identified as being in any one or more of the following subgroups:

- Adults with lived experience of diabetes or DFD or their carers (consumers).

- Health professionals involved in the care of people with diabetes or DFD.

- Researchers or academics involved in diabetes or DFD research.

- Industry representatives such as government agencies involved with diabetes or DFD policy or a commercial organization involved with diabetes or DFD products.

Diabetes was defined as those having been diagnosed with type 1 or type 2 diabetes mellitus. The concept of diabetes-related foot health and disease was considered important in this study as it incorporates both foot disease, as defined as infection or ulceration of the foot of a person with diabetes mellitus usually accompanied by peripheral neuropathy and/or peripheral arterial disease, ${ }^{21}$ and foot health, as defined as maintaining health and well-being while preventing foot disease in those with diabetes but without foot disease.

Eligible participants checked an online consent box at the start of the online survey to provide consent to participate in the study, receive ongoing communication as part of the research, and to acknowledge the three-round design of the study. Participants were free to withdraw at any time. The authors were excluded from participating in the surveys.

\section{Recruitment}

Eligible participants were recruited via multiple invitations and advertisements for the study over a 5-week period during Round 1 in August and September 2020. DFA led all recruitment, with the institutional, social and personal networks of DFA, the Australian Diabetes Society and the authors used. A series of infographics were produced to assist with promotion of the invitations. Emails were further sent using these infographics from DFA to existing DFA email subscribers and promoted weekly on the DFA website, Facebook, Instagram and Twitter social network platforms. Invitations were also sent by email to key peak diabetes, health professional and Aboriginal and Torres Strait Islander bodies to promote the study to members and social media followers. Snowballing and word-of-mouth promotion of the study were encouraged.

\section{Procedure}

All data were collected using the online survey platform Qualtrics software (Qualtrics, Provo, Utah, USA). All rounds were open for at least 4 weeks and participants were reminded weekly to respond. Data were linked at each round through participant-provided email, which was known to only one author (NP). Only participants who completed a previous round could participate in a subsequent round. Each participant who completed Round 1 was assigned a Round 1 unique identifier and then received a personalized survey link via the participantprovided email to complete Round 2. This process was repeated for participants who successfully completed Round 2. All unique identifier data were stored against the participant profile in the Qualtrics system to link the participant data across the three survey rounds. All personalized survey links could only be completed once. No enticements or compensation were provided. There was no communication between participants as a result of the data collection method and participants agreed as part of the consenting process for their responses to each round to be retained. Feedback to participants after Round 1 and Round 2 was provided within the online survey to provide a summary of the previous round's results. The procedure for each of the three rounds is outlined below and summarized in figure 1 .

\section{Round 1}

After each participant provided informed consent, they self-selected the subgroup with which they most 


\section{Round 1}

- Open online invitation via DFA and other networks to participate

- Participants provide up to three responses to: "What questions about diabetes-related foot health and disease would you like to see answered by research"

- 210 participants proposed 434 individual questions, with questions stratified according to 22 diabetesrelated foot categories

- 226 questions proceeded to Round 2

Round 2

- 210 participants from Round 1 invited to complete Round 2, 95 completed (45.2\%)

- Participants selected 10 questions from the 226 questions that matter to them most

- Top ten questions calculated for overall group and the consumers and health professional subgroups

\section{Round 3}

- 95 participants from Round 2 invited to complete Round 3

- 69 participants completed (72.6\%), 39 health professionals and 30 consumers

- Participants ranked the top ten questions identified in Round 2 for overall group and their subgroup, from most important to least important

- Final result: A ranked top ten list of research priorities identified for the overall sample, health professionals and consumers

Figure 1 Participant flow and question development over the three rounds. DFA, Diabetes Feet Australia.

identified. Participants were asked to identify their gender, age grouping, state, territory, postcode and if they identified as an Aboriginal and/or Torres Strait Islander person. Based on the subgroup selected, additional information was collected using survey software logic. This meant that only the questions relevant to the selected subgroup were displayed to the particular participant, for example, health professionals were asked to provide their profession, state and working sector (public/private). All participants were asked the same core survey item questions. Participants then progressed through to the main survey item question, 'What questions about diabetesrelated foot health and disease would you most like to see answered by research? ${ }^{9}$ Participants were required to provide at least one question in response to this item and had the option of providing up to a total of three questions.

\section{Round 2}

To develop Round 2 items, two authors (BMP and AR) used inductive and deductive thematic analyses to initially independently categorize all question responses from Round 1 into DFD subcategories. Categories were aligned with those contained in international guidelines ${ }^{13-18}$ and it was left open for the two authors to inductively create other relevant DFD categories if they felt necessary. Any disagreements in categorization were reviewed and resolved by discussion between the two researchers to reach consensus. This involved each author providing a rationale for their choice and reaching a mutual agreement about which category was more fitting. Where there was a deadlock, a third reviewer was available to decide; however, this was not required. Responses were excluded if the question did not have an element of diabetesrelated foot health or DFD in the question, was unable to be formulated as a question, or was a response asking for personal health advice.

All remaining questions were split among four pairs of authors to consider further exclusions, duplication of responses, and question editing if required. The editing principles used by the author pairs included: minimal disruption to the intent of response question, editing only to improve clarity of the original intent, use of culturally sensitive or person-centered language, and to ensure the end result was in the form of a question. Author pairs independently edited one-half of the questions in their shared list and then reviewed the alternate half. Any disagreements in suggested edits to responses or exclusion were resolved as described above. The consumer representative reviewed all final edited questions to check for readability and accessibility for consumers before finalization for Round 2 . The final list of unique edited questions from Round 1 was grouped according to their DFD category and presented to participants in Round 2 in random order to minimize selection bias. Participants were informed that initially they could select as many questions as they thought important from the entire list provided, before being asked at the conclusion of Round 2 to select a maximum of 10 questions they considered to be most important from the initial selections they identified.

\section{Round 3}

The Round 3 top 10 research questions were determined by identifying the 10 questions most frequently selected by all participants and by participant subgroups after Round 2. Participants were then asked to rank the top 10 questions in order from most to least important. The questions were categorized independently by two authors (BMP and PAL) according to the UK Clinical Research Collaboration Health Research Classification System (UKCRC HRCS). ${ }^{22}$ This system classifies types of research activity according to the following codes: underpinning research; etiology; prevention of diseases and conditions; detection, screening and diagnosis; development of treatments and therapeutic interventions; evaluation of treatments and therapeutic interventions, management of diseases and conditions; and health and social care services research. ${ }^{22}$ Any disagreements were resolved as described above. 


\section{Statistical analyses}

Round 1 responses were sorted within DFD categories using Microsoft Excel 2018 (Microsoft, Redmond, Washington). The frequency with which questions were prioritized (Round 2) and the scoring for final top 10 ranking (Round 3) were analyzed using SPSS V.26. The questions selected most frequently in Round 2 were included in Round 3 items, for the total sample of participants and for the subgroups of health professionals and consumers. If there was a tie for the 10th most frequent question, then all tied questions were also included. In Round 3 , the final top 10 research questions identified by the total sample and the health professional and consumer subgroups were determined by inverse point scoring (eg, rank $1=10$ points) for each participant response. The final results were based on the highest summed points for each question and were then ranked from 1 (highest rank) to 10 (lowest rank) for each group. $\mathrm{X}^{2}$ analysis was undertaken to compare differences in the proportion of responses for participant characteristics from Round 1 to Round 3 with statistical significance defined as $p<0.05$.

\section{RESULTS}

Two hundred and ten participants completed Round 1, including 121 health professionals, 72 consumers (including two carers), 9 researchers and 8 industry representatives. Of those completing Round 1, 95 (45.2\%) also completed Round 2, and of those $69(72.6 \%)$ completed Round 3. Table 1 shows participant characteristics were similar across all rounds ( $>0.05)$, except a higher proportion of females and those with lived experience of DFD completed Round 3 (both, $\mathrm{p}<0.05$ ). Figure 1 summarizes participant involvement in the three rounds with 69 (32.9\% of 210) participants completing all three rounds.

Of the 69 participants completing all three rounds, 36 $(52.2 \%)$ were health professionals, $29(42 \%)$ consumers, $2(2.9 \%)$ researchers, $1(1.4 \%)$ carer and 1 (1.4\%) industry representative. Only one participant identified as an Aboriginal or Torres Strait Islander person. Due to a low number of responses in some categories, the carer responses were consolidated with consumers, and the researchers and industry representative participants were consolidated with the health professional subgroup.

In Round 1, participants provided 434 research question responses. Of those, 208 were excluded due to 121 being duplicates and 87 not meeting the predefined criteria for a question (ie, contain an element of diabetesrelated foot health or disease, be able to be formulated into a question and/or not a request for personal health advice). Thus, 226 unique questions were included after Round 1. These questions were allocated to 22 DFD subcategories (online supplemental table 1) with most questions in 'health services' $(15.9 \%)$ or 'psychosocial or behavioural' (11.5\%) subcategories (online supplemental table 2).
Table 1 Summary of participant characteristics ( $(\%))$

\begin{tabular}{|c|c|c|c|}
\hline Characteristics & Round 1 & Round 2 & Round 3 \\
\hline Total sample & 210 & 95 & 69 \\
\hline \multicolumn{4}{|l|}{ Age (years) } \\
\hline$<30$ & $9(4.3)$ & $4(4.3)$ & $3(4.3)$ \\
\hline 30-39 & $44(21.0)$ & $22(23.2)$ & $14(20.3)$ \\
\hline $40-49$ & $36(17.1)$ & $14(14.7)$ & $9(13.0)$ \\
\hline $50-59$ & $58(27.6)$ & $28(29.5)$ & $20(29.0)$ \\
\hline $60-69$ & $36(17.1)$ & $18(18.9)$ & $15(21.7)$ \\
\hline$>69$ & 27 (12.9) & $9(9.5)$ & $8(11.6)$ \\
\hline Female & $122(58.1)$ & $62(65.3)$ & 47 (68.1)ף \\
\hline $\begin{array}{l}\text { Aboriginal or Torres } \\
\text { Strait Islander person }\end{array}$ & $2(1.0)$ & $1(1.1)$ & $1(1.4)$ \\
\hline \multicolumn{4}{|l|}{ Subgroups } \\
\hline $\begin{array}{l}\text { Live with, or at risk of, } \\
\text { diabetes-related foot } \\
\text { disease (consumer) }\end{array}$ & 70 (33.3) & $34(35.8)$ & $29(42.0)$ \\
\hline $\begin{array}{l}\text { Carer for someone with } \\
\text { diabetes }\end{array}$ & $2(1.0)$ & $1(1.1)$ & $1(1.4)$ \\
\hline Health professional & $121(57.6)$ & $52(54.7)$ & $36(52.2)$ \\
\hline Researcher/academic & $9(4.3)$ & $5(5.3)$ & $2(2.9)$ \\
\hline Industry representative & $8(3.8)$ & $3(3.2)$ & $1(1.4)$ \\
\hline $\begin{array}{l}\text { Health professional } \\
\text { subgroup }\end{array}$ & 121 & 60 & 36 \\
\hline \multicolumn{4}{|l|}{ Professional discipline } \\
\hline Podiatrist & $62(51.2)$ & $31(51.7)$ & $20(55.6)$ \\
\hline Medical practitioner* & $29(24.0)$ & $14(23.3)$ & $6(16.7)$ \\
\hline Nurse & $6(5.0)$ & $3(5.0)$ & $3(8.3)$ \\
\hline Diabetes educator & $8(6.6)$ & $2(3.3)$ & $1(2.8)$ \\
\hline Pedorthist & $5(4.1)$ & $3(5.0)$ & $1(2.8)$ \\
\hline Dietitian & $4(3.3)$ & $2(3.3)$ & $1(2.8)$ \\
\hline Other† & $7(5.8)$ & $4(6.7)$ & $4(11.1)$ \\
\hline \multicolumn{4}{|l|}{ Healthcare sector } \\
\hline Public & $90(74.4)$ & $40(66.7)$ & $28(77.8)$ \\
\hline Private & $25(20.7)$ & $11(18.3)$ & $8(22.2)$ \\
\hline Other $¥$ & $6(5.0)$ & $1(1.7)$ & $0(0)$ \\
\hline \multicolumn{4}{|c|}{ State/territory of health professional } \\
\hline Victoria & $29(24.0)$ & $13(21.7)$ & $5(13.9)$ \\
\hline New South Wales & $24(19.8)$ & $13(21.7)$ & $10(27.8)$ \\
\hline South Australia & $6(5.0)$ & $2(3.3)$ & $2(5.6)$ \\
\hline Queensland & $28(23.1)$ & $12(20.0)$ & $8(22.2)$ \\
\hline Northern Territory & $1(0.8)$ & $1(1.7)$ & $1(2.8)$ \\
\hline $\begin{array}{l}\text { Australian Capital } \\
\text { Territory }\end{array}$ & $1(0.8)$ & $1(1.7)$ & $1(2.8)$ \\
\hline Western Australia & $28(23.1)$ & $15(25.0)$ & $7(19.4)$ \\
\hline Tasmania & $4(3.3)$ & $3(5.0)$ & $2(5.6)$ \\
\hline Consumer subgroup & $\mathrm{n}=72$ & $n=35$ & $n=30$ \\
\hline \multicolumn{4}{|c|}{ Lived experience with diabetes } \\
\hline $\begin{array}{l}\text { Live with, or at risk of, } \\
\text { diabetes-related foot } \\
\text { disease }\end{array}$ & 70 (97.2) & $34(97.1)$ & 29 (96.7) \\
\hline
\end{tabular}

Continued 


\begin{tabular}{|c|c|c|c|}
\hline Characteristics & Round 1 & Round 2 & Round 3 \\
\hline $\begin{array}{l}\text { Carer for someone } \\
\text { with diabetes }\end{array}$ & $2(2.8)$ & $1(2.9)$ & $1(3.3)$ \\
\hline \multicolumn{4}{|c|}{ Level of diabetes-related foot disease } \\
\hline Diabetes & $44(61.1)$ & $18(51.4)$ & $13(43.3)$ \\
\hline $\begin{array}{l}\text { Diabetes-related foot } \\
\text { problems }\end{array}$ & $26(36.1)$ & $16(45.7)$ & $16(53.3)^{\star \star}$ \\
\hline Missing (carer) & $2(2.8)$ & $1(2.9)$ & $1(3.3)$ \\
\hline \multicolumn{4}{|c|}{ State/territory of consumer } \\
\hline Victoria & $34(47.2)$ & $15(42.9)$ & $13(43.3)$ \\
\hline New South Wales & $10(13.9)$ & $5(14.3)$ & $4(13.3)$ \\
\hline South Australia & $0(0)$ & $0(0)$ & $0(0)$ \\
\hline Queensland & $10(13.9)$ & $5(14.3)$ & $4(13.3)$ \\
\hline Northern Territory & $0(0)$ & $0(0)$ & $0(0)$ \\
\hline $\begin{array}{l}\text { Australian Capital } \\
\text { Territory }\end{array}$ & $1(1.3)$ & $1(2.9)$ & $1(0.3)$ \\
\hline Western Australia & $15(20.8)$ & $8(22.9)$ & $7(23.0)$ \\
\hline Tasmania & $0(0)$ & $0(0)$ & $0(0)$ \\
\hline Missing & $2(2.8)$ & $1(2.9)$ & $1(0.3)$ \\
\hline \multicolumn{4}{|c|}{ Geographical classification§ } \\
\hline Metropolitan & $47(65.3)$ & $22(62.9)$ & $19(63.3)$ \\
\hline Regional & $8(11.1)$ & $4(11.4)$ & $3(10.0)$ \\
\hline Rural & $15(20.8)$ & $8(22.9)$ & $7(23.3)$ \\
\hline Remote & $0(0)$ & $0(0)$ & $0(0)$ \\
\hline Missing & $2(2.8)$ & $1(2.9)$ & $1(3.3)$ \\
\hline
\end{tabular}

*Medical practitioners: Round 1 included endocrinologist (10), infectious disease specialist (7), undisclosed doctor, registrar or medical consultant (5), physician (2), vascular surgeon (2), orthopedic surgeon (1), rehabilitation physician (1), general practitioners (1); Round 3 included endocrinologist (3), infectious disease specialist (2), medical consultant (1).

†Other health professional: Round 1 included one each of exercise physiologist, heath practitioner, health service manager, medical microbiologist, occupational therapist, orthotist/prosthetist and pharmacist; Round 3 included one each of health practitioner, health service manager, occupational therapist and orthotist/prosthetist.

fOther health sector: public/private split.

$\S$ Location of consumers described according to Modified Monash Model. ${ }^{50}$ १P $<0.05$.

${ }^{* *} \mathrm{P}<0.01$

Tables 2-4 display the top 10 priority research questions ranked by the total sample, consumer and health professional subgroups, respectively. Table 2 shows the top 10 priority research questions of the total sample covered a diverse range of DFD topics, including health economics, peripheral neuropathy, education, infection, technology, exercise, and nutrition. Tables 3 and 4 show the consumer and health professional subgroups had descriptive differences in the prioritized research questions, with no questions shared by both consumers and health professionals in their respective top 10 lists. The consumer subgroup most frequently prioritized questions related to peripheral neuropathy, assessment/ diagnosis and exercise subcategories; and within UKCRC HRCS subcategories of etiology, detection, screening and diagnosis, and evaluation of new treatments. However, health professionals prioritized questions related to Aboriginal and Torres Strait Islander health outcomes, health economics and infection subcategories; and within UKCRC HRCS subcategories of management of diseases and health and social services.

\section{CONCLUSIONS}

To our knowledge, this is the first study to identify the priority research questions that a wide range of relevant DFD stakeholders consider important. The final national top 10 priority research questions from the Australian DFD stakeholders in this study covered a wide range of DFD and health research categories, which may be explained by differences in the priorities of consumers and health professionals. In terms of health research categories, consumers seemed to prioritize preventionrelated category questions (ie, detection, screening and diagnosis, and evaluation of new treatment), whereas health professionals prioritized management-related category questions (ie, existing management of diseases, and health services research). This trend was further evident in specific DFD categories where consumers prioritized prevention-related DFD category topics (ie, neuropathy, assessment/diagnosis and exercise questions) and health professional management-related topics (ie, health economics and infection questions).

The overall top-ranked question from the total sample potentially reflects the uncertainty that stakeholders have about the health and economic benefits of multidisciplinary DFD services. Multidisciplinary DFD services have long been shown to significantly improve health outcomes $^{23-25}$ and implementation of best practice DFD treatments has been shown to be cost-effective in managing DFD. ${ }^{26-28}$ However, global research has also shown that multidisciplinary DFD services are heterogenous in composition and function, ${ }^{29}{ }^{30}$ and implementation of best practice treatments is infrequent in real-world practice. ${ }^{31}$ Thus, perhaps it is no surprise that Australian DFD stakeholders are most interested in testing and identifying the health and economic outcomes of existing services. However, according to our findings, this is more of a priority for health professionals than consumers.

While it was expected that the subgroups of consumers and health professionals may show contrasting priorities, the degree of difference was somewhat surprising. Consumer questions focused on prevention-related topics such as etiology, detection, screening and diagnosis of DFD, with specific research on the detection and treatment of peripheral neuropathy (and neuropathic pain) prioritized. This is similar to findings by Diabetes UK, where the cause, prevention and treatment of peripheral neuropathy were prioritized by stakeholders involved with type 2 diabetes, especially consumers. ${ }^{9}$ These findings are perhaps understandable, as peripheral neuropathy is a major risk factor for DFD, has significant impacts on quality of life, ${ }^{33}$ there are few effective treatments for neuropathic pain compared with other diabetes complications, ${ }^{34}$ and there is a cognitive and emotional impact of being at 
Table 2 Final 'top-10' research questions for the whole sample after Round $3(n=69)$ comparing the rank in consumer or health professional subgroups

\begin{tabular}{|c|c|c|c|c|c|c|}
\hline $\begin{array}{l}\text { Overall sample } \\
\text { rank }\end{array}$ & $\begin{array}{l}\text { Consumer } \\
\text { rank }\end{array}$ & $\begin{array}{l}\text { Health professional } \\
\text { rank }\end{array}$ & Research question & DFD category & $\begin{array}{l}\text { UKCRC HRCS } \\
\text { category }\end{array}$ & $\begin{array}{l}\text { Final } \\
\text { score }\end{array}$ \\
\hline 1 & & 2 & $\begin{array}{l}\text { What are the health and cost benefits } \\
\text { of providing government-funded, } \\
\text { multidisciplinary high-risk foot services } \\
\text { for optimal management of people } \\
\text { with diabetes-related foot disease } \\
\text { compared with usual care? }\end{array}$ & Economics & $\begin{array}{l}\text { Health and social } \\
\text { care services } \\
\text { research }\end{array}$ & 452 \\
\hline 2 & 4 & & $\begin{array}{l}\text { What are the most effective } \\
\text { treatment options for pain associated } \\
\text { with diabetes-related peripheral } \\
\text { neuropathy? }\end{array}$ & $\begin{array}{l}\text { Peripheral } \\
\text { neuropathy }\end{array}$ & $\begin{array}{l}\text { Management of } \\
\text { diseases and } \\
\text { conditions }\end{array}$ & 431 \\
\hline 3 & & 4 & $\begin{array}{l}\text { What are the most effective } \\
\text { educational programs to improve self- } \\
\text { care practices to prevent foot disease } \\
\text { in people with diabetes? }\end{array}$ & Education & $\begin{array}{l}\text { Management of } \\
\text { diseases and } \\
\text { conditions }\end{array}$ & 430 \\
\hline 4 & & 3 & $\begin{array}{l}\text { What are the long-term outcomes } \\
\text { (wound recurrence, osteomyelitis } \\
\text { recurrence) of osteomyelitis in } \\
\text { people with diabetes, when treated } \\
\text { conservatively/medically rather than } \\
\text { surgically? }\end{array}$ & Infection & $\begin{array}{l}\text { Management of } \\
\text { diseases and } \\
\text { conditions }\end{array}$ & 413 \\
\hline 5 & 1 & & $\begin{array}{l}\text { Can established peripheral neuropathy } \\
\text { be reversed, and if so how? }\end{array}$ & $\begin{array}{l}\text { Peripheral } \\
\text { neuropathy }\end{array}$ & Etiology & 410 \\
\hline 6 & & 5 & $\begin{array}{l}\text { Is there a cost benefit of implementing } \\
\text { a program to prevent diabetes-related } \\
\text { foot ulcers in high-risk populations } \\
\text { compared with the cost of treating } \\
\text { diabetes-related foot ulcers? }\end{array}$ & Economics & $\begin{array}{l}\text { Health and social } \\
\text { care services } \\
\text { research }\end{array}$ & 381 \\
\hline 7 & & & $\begin{array}{l}\text { What smart technology can be } \\
\text { integrated into the care of people with } \\
\text { diabetes-related foot ulcers that will } \\
\text { help improve healing time? }\end{array}$ & Technology & $\begin{array}{l}\text { Evaluation of } \\
\text { treatments and } \\
\text { therapeutic } \\
\text { interventions }\end{array}$ & 332 \\
\hline 8 & 8 & & $\begin{array}{l}\text { Is exercise beneficial in reducing } \\
\text { the risk of diabetes-related foot } \\
\text { complication? }\end{array}$ & Exercise & $\begin{array}{l}\text { Evaluation of } \\
\text { treatments and } \\
\text { therapeutic } \\
\text { interventions }\end{array}$ & 327 \\
\hline 9 & & & $\begin{array}{l}\text { What is the effectiveness of diet } \\
\text { supplementation with micronutrients } \\
\text { such as vitamins, protein, minerals and } \\
\text { amino acids in improving healing rates } \\
\text { in people with diabetes-related foot } \\
\text { disease or ulcers? }\end{array}$ & Nutrition & $\begin{array}{l}\text { Evaluation of } \\
\text { treatments and } \\
\text { therapeutic } \\
\text { interventions }\end{array}$ & 322 \\
\hline 10 & & & $\begin{array}{l}\text { Is exercise safe for people with } \\
\text { diabetes-related foot complications? }\end{array}$ & Exercise & $\begin{array}{l}\text { Evaluation of } \\
\text { treatments and } \\
\text { therapeutic } \\
\text { interventions }\end{array}$ & 297 \\
\hline
\end{tabular}

DFD, diabetes-related foot disease; UKCRC HRCS, UK Clinical Research Collaboration Health Research Classification System.

high risk for DFD. ${ }^{35}$ Furthermore, consumers prioritized exercise-related questions. The safety, efficacy and effectiveness of exercise in relation to DFD have historically been a controversial topic, with recent data suggesting that prescribed exercise may in fact be safe in this population and may have benefits on preventing and treating peripheral neuropathy in addition to general health benefits. ${ }^{36} 37$ There is, however, no evidence from large randomized controlled trials that exercise prevents DFD or improves outcomes in people with DFD. ${ }^{18}{ }^{38}$ Regardless, these priority exercise-related questions indicate that consumers would like more definitive answers on the benefit and risks of exercise on their DFD outcomes.
In contrast, health professionals prioritized research questions relating more to health services research and management of DFD. The top-ranked question for health professionals focused on improving outcomes for Aboriginal and Torres Strait Islander peoples, particularly those living in remote communities. This high prioritization by health professionals is important as the burden of DFD for Aboriginal and Torres Strait Islander people in Australia is disproportionately high compared with non-Indigenous Australians and potentially recognizes the dearth of DFD research in this important population. ${ }^{39}$ Research into educational programs to improve preventative self-care practices, including offloading 


\begin{tabular}{|c|c|c|c|c|c|}
\hline $\begin{array}{l}\text { Consumer } \\
\text { rank }\end{array}$ & $\begin{array}{l}\text { Overall sample } \\
\text { rank }\end{array}$ & Research question & DFD category & $\begin{array}{l}\text { UKCRC HRCS } \\
\text { category }\end{array}$ & Total score \\
\hline 2 & & $\begin{array}{l}\text { What are some of the early signs a person } \\
\text { with diabetes must be aware of that they are } \\
\text { developing diabetes-related foot problems? }\end{array}$ & Assessment/diagnosis & $\begin{array}{l}\text { Detection, screening } \\
\text { and diagnosis }\end{array}$ & 183 \\
\hline 4 & 2 & $\begin{array}{l}\text { What are the most effective treatment options for } \\
\text { pain associated with diabetes-related peripheral } \\
\text { neuropathy? }\end{array}$ & Peripheral neuropathy & $\begin{array}{l}\text { Management of } \\
\text { diseases and } \\
\text { conditions }\end{array}$ & 173 \\
\hline 7 & & $\begin{array}{l}\text { What are the symptoms of diabetes-related foot } \\
\text { complications? }\end{array}$ & Assessment/diagnosis & $\begin{array}{l}\text { Detection, screening } \\
\text { and diagnosis }\end{array}$ & 142 \\
\hline 8 & 8 & $\begin{array}{l}\text { Is exercise beneficial in reducing the risk of } \\
\text { diabetes-related foot complication? }\end{array}$ & Exercise & $\begin{array}{l}\text { Evaluation of } \\
\text { treatments and } \\
\text { therapeutic } \\
\text { interventions }\end{array}$ & 124 \\
\hline 9 & & $\begin{array}{l}\text { Are people with diabetes aware of how peripheral } \\
\text { neuropathy affects their feet and how to check } \\
\text { for it? }\end{array}$ & Education & $\begin{array}{l}\text { Detection, screening } \\
\text { and diagnosis }\end{array}$ & 123 \\
\hline 10 & & $\begin{array}{l}\text { Is exercise beneficial in improving symptoms of } \\
\text { painful peripheral neuropathy? }\end{array}$ & Exercise & $\begin{array}{l}\text { Evaluation of } \\
\text { treatments and } \\
\text { therapeutic } \\
\text { interventions }\end{array}$ & 114 \\
\hline
\end{tabular}

DFD, diabetes-related foot disease; UKCRC HRCS, UK Clinical Research Collaboration Health Research Classification System.

adherence, was also prioritized by health professionals. This may reflect the challenges people with DFD have with self-care and how important it is for health professionals to understand the psychological and behavioral mechanisms of feasible and effective self-care behavior in this population. ${ }^{35}$ There were also management-related priority questions that aimed to address the uncertainties around resolving infection, which included research into the comparative effectiveness of medical versus surgical treatment of osteomyelitis and length of antibiotic duration. ${ }^{15}$ This has also been an area of much debate for some time and more definitive data are required to assist health professionals with their clinical decision-making to resolve infection. ${ }^{40}$ Lower ranked in the health professionals' top 10 priorities was the use of standardized clinical pathways to improve consistency of care. While clinical pathways have been shown to improve care and reduce DFD-related hospitalizations in certain populations in Australia, ${ }^{41}{ }^{42}$ current national guidelines on which they are based are now over 10 years old. ${ }^{43}$ While new Australian national DFD guidelines have been launched in late $2021,{ }^{44}$ more research is required to identify the most effective ways to implement best practice into clinical practice.

Most previous studies investigating priority research questions in other health conditions have also used a similar consensus building technique to this study, but with differing procedures and population focus. ${ }^{9} 10$ 45-49 Yet, unlike our study most previous similar studies have recruited health professionals only, ${ }^{104648} 49$ with fewer including consumers with a lived experience of the condition concerned. ${ }^{9}{ }^{4547}$ An important previous study from the James Lind Alliance and Diabetes UK using a priority setting partnership approach with strong consumer input identified the top 10 research priority questions for people with type 2 diabetes and also found differences between health professionals and consumers. ${ }^{9}$ In this Diabetes UK study, the only top diabetes research question that was related to DFD focused on the prevention and treatment of peripheral neuropathy and was given much higher priority by consumers living with diabetes than by health professionals. ${ }^{9}$ Prevention has also been a focus of research priority question development for general foot health, with prevention of ulceration and other diabetes-related foot problems highlighted in two of the top 10 research questions identified. ${ }^{45}$ It is clear from our collective findings that it is important to include consumers in DFD research priority setting, as consumer research priorities cannot be simply assumed by researchers and are likely to emphasize the importance of prevention, an underfunded and under-researched area of DFD. ${ }^{18}$ 
Table 4 Final 'top-10' research questions for health professionals after Round $3\left(n=39^{\star}\right)$, compared with rank from overall sample

\begin{tabular}{|c|c|c|c|c|c|}
\hline $\begin{array}{l}\text { Health professional } \\
\text { rank }\end{array}$ & $\begin{array}{l}\text { Overall sample } \\
\text { rank }\end{array}$ & Research question & DFD category & UKCRC HRCS category & $\begin{array}{l}\text { Total } \\
\text { score }\end{array}$ \\
\hline 1 & & $\begin{array}{l}\text { How can we improve outcomes of } \\
\text { diabetes-related foot complications for } \\
\text { Aboriginal and Torres Strait Islander } \\
\text { people, particularly those living in remote } \\
\text { communities? }\end{array}$ & $\begin{array}{l}\text { Aboriginal and Torres } \\
\text { Strait Islander health }\end{array}$ & $\begin{array}{l}\text { Management of diseases } \\
\text { and conditions }\end{array}$ & 214 \\
\hline 2 & 1 & $\begin{array}{l}\text { What are the health and cost benefits } \\
\text { of providing government-funded, } \\
\text { multidisciplinary high-risk foot services } \\
\text { for optimal management of people with } \\
\text { diabetes-related foot disease compared } \\
\text { with usual care? }\end{array}$ & Economics & $\begin{array}{l}\text { Health and social care } \\
\text { services research }\end{array}$ & 212 \\
\hline 3 & 4 & $\begin{array}{l}\text { What are the long-term outcomes } \\
\text { (wound recurrence, osteomyelitis } \\
\text { recurrence) of osteomyelitis in } \\
\text { people with diabetes, when treated } \\
\text { conservatively/medically rather than } \\
\text { surgically? }\end{array}$ & Infection & $\begin{array}{l}\text { Management of diseases } \\
\text { and conditions }\end{array}$ & 188 \\
\hline 4 & 3 & $\begin{array}{l}\text { What are the most effective educational } \\
\text { programs to improve self-care practices } \\
\text { to prevent foot disease in people with } \\
\text { diabetes? }\end{array}$ & Education & $\begin{array}{l}\text { Management of diseases } \\
\text { and conditions }\end{array}$ & 185 \\
\hline 5 & 6 & $\begin{array}{l}\text { Is there a cost benefit of implementing a } \\
\text { program to prevent diabetes-related foot } \\
\text { ulcers in high-risk populations compared } \\
\text { with the cost of treating diabetes-related } \\
\text { foot ulcers? }\end{array}$ & Economics & $\begin{array}{l}\text { Health and social care } \\
\text { services research }\end{array}$ & 177 \\
\hline 6 & & $\begin{array}{l}\text { What are the most effective treatment } \\
\text { approaches to help people with diabetes } \\
\text { adhere to using their recommended } \\
\text { offloading devices? }\end{array}$ & Offloading & $\begin{array}{l}\text { Management of diseases } \\
\text { and conditions }\end{array}$ & 167 \\
\hline 7 & & $\begin{array}{l}\text { How can state and federal governments } \\
\text { be engaged to better fund the } \\
\text { community care of people with, or at risk } \\
\text { of, diabetes-related foot disease? }\end{array}$ & Health services & $\begin{array}{l}\text { Health and social care } \\
\text { services research }\end{array}$ & 167 \\
\hline 8 & & $\begin{array}{l}\text { Do standardized clinical pathways } \\
\text { improve the consistency of care for } \\
\text { people with diabetes-related foot } \\
\text { disease? }\end{array}$ & $\begin{array}{l}\text { Translational } \\
\text { research }\end{array}$ & $\begin{array}{l}\text { Management of diseases } \\
\text { and conditions }\end{array}$ & 158 \\
\hline 9 & & $\begin{array}{l}\text { What is the best duration for antibiotics } \\
\text { in the management of osteomyelitis? }\end{array}$ & Infection & $\begin{array}{l}\text { Management of diseases } \\
\text { and conditions }\end{array}$ & 125 \\
\hline 10 & & $\begin{array}{l}\text { What are the amputation rates in } \\
\text { different local government areas in } \\
\text { Australia? }\end{array}$ & Epidemiology & $\begin{array}{l}\text { Health and social care } \\
\text { services research }\end{array}$ & 116 \\
\hline
\end{tabular}

*Group consolidated 36 health professionals, 2 researchers/academics and 1 industry.

DFD, diabetes-related foot disease; UKCRC HRCS, UK Clinical Research Collaboration Health Research Classification System.

The strengths of this study included the wide range of stakeholders who participated, with a particularly strong consumer and health professional voice. The Delphi design used also aligned with previous frameworks ${ }^{9} 10$ and was an efficient and transparent process to determine the priorities from such a diverse sample of participants. There was a drop in participation retention rate in Round 2; however, overall participation rates were generally consistent with previous studies from other disciplines and conditions ${ }^{46-49}$ and the characteristics of participants in each round were very similar. Participation rates may though have been affected by the large number of questions that participants were asked to select from in Round 2, the impact of the coronavirus pandemic, and rounds occurring over the Australian traditional holiday period of December/January. Finally, there was very limited participation from Aboriginal and Torres Strait Islander people and thus the priority research questions identified in this study cannot be considered reflective of the importance to Aboriginal and Torres Strait Islander peoples. It is strongly recommended that future similar studies investigate the priority research questions of Aboriginal and Torres Strait Islander peoples using a more personal approach such as culturally appropriate, qualitative, focus group study designs.

The findings from this study should guide future national research agendas that pursue answers to these important priority research questions and in turn 
contribute to the reduction of the comparatively large disease burden caused by DFD on patients and nations. In the short term though, these findings should help facilitate diabetes-focused research granting bodies to establish criteria to target researchers and research funding towards these national priority research questions as has happened for diabetes research. ${ }^{9}$ In the longer term, these findings should assist diabetes peak bodies in lobbying government for targeted research funding which can help to bridge the current funding gap between the high DFD burden and low DFD research funding to address this burden. Lastly, in addition to future research investigating the perspectives of Aboriginal and Torres Strait Islander peoples, it is recommended that future studies from other nations investigate to determine if the priority research question findings of this Australian study are generalizable globally to other nations.

In conclusion, the findings from this study have identified national stakeholder-agreed priority research questions for DFD for the first time. The research questions identified potentially reflect the diversity in priorities across health professionals and consumers. Importantly, though, they also emphasize the need to prioritize research into typically under-researched areas of DFD, such as the prevention, diagnosis and treatment of peripheral neuropathy, and improving Aboriginal and Torres Strait Islander people DFD outcomes. Furthermore, they confirm the more established research need for more DFD research into effectiveness of health service delivery models and therapeutic interventions for diabetes-related foot infection.

\author{
Author affiliations \\ 'La Trobe Rural Health School, La Trobe University, Bendigo, Victoria, Australia \\ ${ }^{2}$ Diabetes Feet Australia, Sydney, New South Wales, Australia \\ ${ }^{3}$ Discipline of Podiatry, La Trobe University, Melbourne, Victoria, Australia \\ ${ }^{4}$ School of Primary and Allied Health Care, Monash University, Frankston, Victoria, \\ Australia \\ ${ }^{5}$ Faculty of Medicine and Health, The University of Sydney, Camperdown, New \\ South Wales, Australia \\ ${ }^{6}$ Department of Endocrinology, Royal Prince Alfred Hospital, Camperdown, New \\ South Wales, Australia \\ ${ }^{7}$ Queensland Research Centre for Peripheral Vascular Disease, James Cook \\ University, Townsville, Queensland, Australia \\ ${ }^{8}$ Department of Vascular and Endovascular Surgery, Townsville University Hospital, \\ Townsville, Queensland, Australia \\ ${ }^{9}$ Department of Endocrinology, Fiona Stanley Hospital, Perth, Western Australia, \\ Australia \\ ${ }^{10}$ Medical School, University of Western Australia, Perth, Western Australia, Australia \\ ${ }^{11}$ Diabetes Centre, High Risk Foot Service, Royal Prince Alfred Hospital, \\ Camperdown, New South Wales, Australia \\ ${ }^{12}$ Consumer representative, Melbourne, Victoria, Australia \\ ${ }^{13}$ Rehabilitation Medicine, Amsterdam UMC, Amsterdam, Netherlands \\ ${ }^{14}$ School of Public Health and Social Work, Queensland University of Technology, \\ Brisbane, Queensland, Australia \\ ${ }^{15}$ Allied Health Research Collaborative, The Prince Charles Hospital, Brisbane, \\ Queensland, Australia
}

Acknowledgements This study was a collaborative project between Diabetes Feet Australia (a division of the Australian Diabetes Society) and La Trobe University. Diabetes Feet Australia provided in-kind secretarial support and oversight.
Contributors BMP and PAL conceived the study. BMP, AR, CMW and PAL designed the study, with all authors reviewing, contributing and approving the design. All authors contributed to the data screening, question categorization and question editing. BMP undertook the analysis, with all authors reviewing and contributing. BMP drafted the manuscript and all authors critically reviewed the manuscript and approved the final version for submission. BMP is responsible for the overall content of the manuscript as the guarantor.

Funding Podiatrists Registration Board of Victoria (novated to the Podiatry Education Trust) provided financial assistance with this project.

Competing interests None declared.

Patient consent for publication Not required.

Ethics approval The La Trobe University Human Research Ethics Committee (HEC20282) approved this research.

Provenance and peer review Not commissioned; externally peer reviewed.

Data availability statement All data relevant to the study are included in the article or uploaded as supplemental information.

Supplemental material This content has been supplied by the author(s). It has not been vetted by BMJ Publishing Group Limited (BMJ) and may not have been peer-reviewed. Any opinions or recommendations discussed are solely those of the author(s) and are not endorsed by BMJ. BMJ disclaims all liability and responsibility arising from any reliance placed on the content. Where the content includes any translated material, BMJ does not warrant the accuracy and reliability of the translations (including but not limited to local regulations, clinical guidelines, terminology, drug names and drug dosages), and is not responsible for any error and/or omissions arising from translation and adaptation or otherwise.

Open access This is an open access article distributed in accordance with the Creative Commons Attribution Non Commercial (CC BY-NC 4.0) license, which permits others to distribute, remix, adapt, build upon this work non-commercially, and license their derivative works on different terms, provided the original work is properly cited, appropriate credit is given, any changes made indicated, and the use is non-commercial. See: http://creativecommons.org/licenses/by-nc/4.0/.

ORCID iDs

Byron M Perrin http://orcid.org/0000-0003-4616-3510

Jonathan Golledge http://orcid.org/0000-0002-5779-8848

Jaap J van Netten http://orcid.org/0000-0002-6420-6046

Peter A Lazzarini http://orcid.org/0000-0002-8235-7964

\section{REFERENCES}

1 Lazzarini PA, Pacella RE, Armstrong DG, et al. Diabetes-related lower-extremity complications are a leading cause of the global burden of disability. Diabet Med 2018;35:1297-9.

2 Zhang Y, Lazzarini PA, McPhail SM, et al. Global disability burdens of diabetes-related lower-extremity complications in 1990 and 2016. Diabetes Care 2020;43:964-74.

3 Kerr M, Barron E, Chadwick P, et al. The cost of diabetic foot ulcers and amputations to the National health service in England. Diabet Med 2019;36:995-1002.

4 Lazzarini PA, Hurn SE, Kuys SS, et al. The silent overall burden of foot disease in a representative hospitalised population. Int Wound $J$ 2017:14:716-28.

5 Jeffcoate WJ, Vileikyte L, Boyko EJ, et al. Current challenges and opportunities in the prevention and management of diabetic foot ulcers. Diabetes Care 2018;41:645-52.

6 Armstrong DG, Kanda VA, Lavery LA, et al. Mind the gap: disparity between research funding and costs of care for diabetic foot ulcers. Diabetes Care 2013;36:1815-7.

7 Lazzarini PA, van Netten JJ, Fitridge RA, et al. Pathway to ending avoidable diabetes-related amputations in Australia. Med J Aust 2018;209:288-90.

8 van Netten JJ, Lazzarini PA, Fitridge R, et al. Australian diabetesrelated foot disease strategy 2018-2022: the first step towards ending avoidable amputations within a generation. Brisbane: Diabetic Foot Australia, Wound Management Innovations CRC, 2017. https://www.diabetesfeetaustralia.org/wp-content/uploads/ 2020/12/Australian-diabetes-related-foot-disease-strategy-20182022-DFA2020.pdf

9 Finer S, Robb P, Cowan K, et al. Setting the top 10 research priorities to improve the health of people with type 2 diabetes: a diabetes UK-James Lind alliance priority setting partnership. Diabet Med 2018;35:862-70. 
10 Smith GE, Long J, Wallace T, et al. Identifying the research priorities of healthcare professionals in UK vascular surgery: modified Delphi approach. BJS Open 2021;5. doi:10.1093/bjsopen/zraa025. [Epub ahead of print: 0503 2021].

11 Yoshida S. Approaches, tools and methods used for setting priorities in health research in the 21 (st) century. $J$ Glob Health 2016;6:010507-07.

12 Diabetes UK. Patient and public involvement (PPi) in your study: diabetes UK, 2021. Available: https://www.diabetes.org.uk/research/ for-researchers/apply-for-a-grant/help-with-involving-participants [Accessed 17 May 2021].

13 Bus SA, Armstrong DG, Gooday C, et al. Guidelines on offloading foot ulcers in persons with diabetes (IWGDF 2019 update). Diabetes Metab Res Rev 2020;36(Suppl 1):e3274.

14 Hinchliffe RJ, Forsythe RO, Apelqvist J, et al. Guidelines on diagnosis, prognosis, and management of peripheral artery disease in patients with foot ulcers and diabetes (IWGDF 2019 update). Diabetes Metab Res Rev 2020;36(Suppl 1):e3276.

15 Lipsky BA, Senneville Éric, Abbas ZG, et al. Guidelines on the diagnosis and treatment of foot infection in persons with diabetes (IWGDF 2019 update). Diabetes Metab Res Rev 2020;36(Suppl)1:e3280.

16 Monteiro-Soares M, Russell D, Boyko EJ, et al. Guidelines on the classification of diabetic foot ulcers (IWGDF 2019). Diabetes Metab Res Rev 2020;36(Suppl 1):e3273.

17 Rayman G, Vas P, Dhatariya K, et al. Guidelines on use of interventions to enhance healing of chronic foot ulcers in diabetes (IWGDF 2019 update). Diabetes Metab Res Rev 2020;36(Suppl 1):e3283.

18 Bus SA, Lavery LA, Monteiro-Soares M, et al. Guidelines on the prevention of foot ulcers in persons with diabetes (IWGDF 2019 update). Diabetes Metab Res Rev 2020;36(Suppl 1):e3269.

19 Keeney S, McKenna H, Hasson F. The Delphi technique in nursing and health research. Chicester, UK: John Wiley \& Sons, Incorporated, 2011.

20 Finer S, Robb P, Cowan K, et al. Top ten research priorities for type 2 diabetes: results from the diabetes UK-James Lind alliance priority setting partnership. Lancet Diabetes Endocrinol 2017;5:935-6.

21 van Netten JJ, Bus SA, Apelqvist J, et al. Definitions and criteria for diabetic foot disease. Diabetes Metab Res Rev 2020;36 Suppl $1: e 3268$.

22 UK Clinical Research Collaboration. UKCRC health research classification system, 2020. Available: https://hrcsonline.net/ research-activities/ [Accessed 3 Jun 2020].

23 Albright RH, Manohar NB, Murillo JF, et al. Effectiveness of multidisciplinary care teams in reducing major amputation rate in adults with diabetes: A systematic review \& meta-analysis. Diabetes Res Clin Pract 2020;161:107996.

24 Blanchette V, Brousseau-Foley M, Cloutier L. Effect of contact with podiatry in a team approach context on diabetic foot ulcer and lower extremity amputation: systematic review and meta-analysis. J Foot Ankle Res 2020;13:15.

25 Meza-Torres B, Carinci F, Heiss C, et al. Health service organisation impact on lower extremity amputations in people with type 2 diabetes with foot ulcers: systematic review and meta-analysis. Acta Diabetol 2021;58:735-47.

26 Cheng Q, Lazzarini PA, Gibb M, et al. A cost-effectiveness analysis of optimal care for diabetic foot ulcers in Australia. Int Wound $J$ 2017;14:616-28.

27 Ortegon MM, Redekop WK, Niessen LW. Cost-effectiveness of prevention and treatment of the diabetic foot: a Markov analysis. Diabetes Care 2004;27:901-7.

28 Ragnarson Tennvall G, Apelqvist J. Prevention of diabetes-related foot ulcers and amputations: a cost-utility analysis based on Markov model simulations. Diabetologia 2001;44:2077-87.

29 Vo UG, Gilfillan M, Hamilton EJ, et al. Availability and service provision of multidisciplinary diabetes foot units in Australia: a crosssectional survey. J Foot Ankle Res 2021;14:27.

30 Musuuza J, Sutherland BL, Kurter S, et al. A systematic review of multidisciplinary teams to reduce major amputations for patients with diabetic foot ulcers. J Vasc Surg 2020;71:1433-46.
31 Prompers L, Huijberts M, Apelqvist J, et al. Delivery of care to diabetic patients with foot ulcers in daily practice: results of the Eurodiale study, a prospective cohort study. Diabet Med 2008;25:700-7.

32 Zhang Y, Cramb S, McPhail SM, et al. Factors associated with healing of diabetes-related foot ulcers: observations from a large prospective real-world cohort. Diabetes Care 2021;44:e143-5.

33 Girach A, Julian TH, Varrassi G, et al. Quality of life in painful peripheral neuropathies: a systematic review. Pain Res Manag 2019;2019:1-9.

34 American Diabetes Association. 11. Microvascular Complications and Foot Care: standards of medical care in diabetes-2021. Diabetes Care 2021:44:S151-67.

35 Vileikyte L, Pouwer F, Gonzalez JS. Psychosocial research in the diabetic foot: are we making progress? Diabetes Metab Res Rev 2020;36(Suppl 1):e3257.

36 Kluding PM, Bareiss SK, Hastings M, et al. Physical training and activity in people with diabetic peripheral neuropathy: paradigm shift. Phys Ther 2017;97:31-43.

37 Zilliox LA, Russell JW. Physical activity and dietary interventions in diabetic neuropathy: a systematic review. Clin Auton Res 2019;29:443-55.

38 Lazzarini PA, Crews RT, van Netten JJ, et al. Measuring plantar tissue stress in people with diabetic peripheral neuropathy: a critical concept in diabetic foot management. J Diabetes Sci Technol 2019:13:869-80.

39 West M, Chuter V, Munteanu S, et al. Defining the gap: a systematic review of the difference in rates of diabetes-related foot complications in Aboriginal and Torres Strait Islander Australians and non-Indigenous Australians. J Foot Ankle Res 2017;10:48.

40 Commons RJ, Raby E, Athan E, et al. Managing diabetic foot infections: a survey of Australasian infectious diseases clinicians. $J$ Foot Ankle Res 2018;11:13

41 Lazzarini PA, O'Rourke SR, Russell AW, et al. Standardising practices improves clinical diabetic foot management: the Queensland diabetic foot innovation project, 2006-09. Aust Health Rev 2012;36:8-15.

42 Lazzarini PA, O'Rourke SR, Russell AW, et al. Reduced incidence of foot-related hospitalisation and amputation amongst persons with diabetes in Queensland, Australia. PLoS One 2015;10:e0130609.

43 Baker IDI Heart and Diabetes Institute, The George Institute for Global Health, Adelaide Health Technology Assessment. National evidence-based guideline on prevention, identification and management of foot complications in diabetes (part of the guidelines on management of type 2 diabetes). Melbourne, Australia, 2011.

44 Lazzarini PA, Raspovic A, Prentice J, et al. Guidelines development protocol and findings: part of the 2021 Australian evidence-based guidelines for diabetes-related foot disease. Brisbane: Diabetes Feet Australia, Australian Diabetes Society, 2021. https://www.diabetes feetaustralia.org/new-guidelines/

45 James Lind Alliance. Foot health top 10, 2019. Available: https:// www.jla.nihr.ac.uk/priority-setting-partnerships/foot-health/top-10priorities.htm [Accessed 09 Jul 2021].

46 Bäck-Pettersson S, Hermansson E, Sernert N, et al. Research priorities in nursing--a Delphi study among Swedish nurses. J Clin Nurs 2008;17:2221-31.

47 Hamlet $\mathrm{C}$, Rumsey N, Williamson $\mathrm{H}$, et al. Consensus research priorities for facial palsy: a Delphi survey of patients, carers, clinicians and researchers. J Plast Reconstr Aesthet Surg 2018;71:1777-84.

48 Tume LN, van den Hoogen A, Wielenga JM, et al. An electronic Delphi study to establish pediatric intensive care nursing research priorities in twenty European countries*. Pediatr Crit Care Med 2014;15:e206-13.

49 Ramelet AS, Gill F, ACCCN Paediatric Intensive Care Special Interest Group. A Delphi study on national PICU nursing research priorities in Australia and New Zealand. Aust Crit Care 2012;25:41-57.

50 Department of Health. Modified Monash model: Commonwealth government of Australia. Available: https://www.health.gov.au/ health-topics/health-workforce/health-workforce-classifications/ modified-monash-model [Accessed 15 Jun 2021]. 